\title{
KEPASTIAN HUKUM PEMILIKAN HAK ATAS TANAH DI KAWASAN TANAH HAK PENGELOLAAN MANDALIKA RESORT (ANALISIS HUKUM PUTUSAN MAHKAMAH AGUNG NOMOR $293 / \mathrm{K} / \mathrm{TUN} / \mathbf{2 0 0 9}$ )
}

\author{
LEGAL CERTAINTY ON THE RIGHT OF LAND OWNERSHIP \\ IN THE RIGHT OF MANAGEMENT MANDALIKA RESORT \\ AREA (JURIDICAL ANALYSIS SUPREME COURT NUMBER \\ 293/K/TUN/2009)
}

\author{
Sahnan \\ Universitas Mataram \\ Email: sahnan_mih@yahoo.co.id
}

\begin{abstract}
The purpose of this study consists of (1) understanding the regulation on the right of land management. (2). Understanding legal certainty on the right of land ownership in the right of management Mandalika Resort area. This article is normative legal research. The result of this study was as follows: (1). regulation on the right of management comes from the rights of controlled by the State based on Article 33 paragraph 3 The 1945 Constitution of the Republic of Indonesia. The regulation on the right of management could be found on UUPA, even though the rule mentioned very implicit in the General explanation at point 2 number 2 . And all this time, the regulation relating to the right of management has regulated in Government regulation $(P P)$ and other regulations that equal to regulation by a minister and National Land Agency. (2). However, the court has given won the lawsuit or court accepted a part of the suit from the heirs of the deceased of Haji Lalu Sapri CS on his land in Mandalika Resort Area against PT. Pengembangan Pariwisata Lombok (PT. LTDC). But still, until now, the land status has not clear or has no legal certainty. Furthermore, the National Land Agency in Center Lombok regency does not want to process the issuance of a certificate submitted by the heirs of Haji Lalu Sapri CS. The National Land Agency in Center Lombok regency still argues that land which is winning by heirs of Haji Lalu Sapri CS is still land State. The Supreme Court decision does not revoke this land state status, and the supreme court decision only revoked the giving of the Right of Building.
\end{abstract}

Keywords: Legal Certainty on The Right of Land Ownership

\begin{abstract}
Abstrak
Tujuan dari penelitian ini terdiri dari (1) memahami peraturan tentang hak pengelolaan lahan. (2) Memahami kepastian hukum tentang hak kepemilikan tanah di dalam hak pengelolaan kawasan Mandalika Resort. Artikel ini adalah penelitian hukum normatif. Hasil penelitian ini adalah sebagai berikut: (1). Peraturan tentang hak pengelolaan berasal dari hak-hak yang dikendalikan oleh Negara berdasarkan Pasal 33 ayat 3 Undang-Undang Dasar Negara Republik Indonesia Tahun 1945. Peraturan tentang hak manajemen dapat ditemukan pada UUPA, meskipun aturan tersebut sangat implisit dalam penjelasan umum pada poin 2 angka 2. Dan selama ini, peraturan yang berkaitan dengan hak manajemen telah diatur dalam peraturan pemerintah. (PP) dan peraturan lainnya yang setara dengan peraturan oleh menteri dan Badan Pertanahan Nasional. (2) Namun, pengadilan telah memenangkan gugatan atau pengadilan menerima bagian dari hukum dari ahli waris almarhum
\end{abstract}


Haji Kemudian Sapri CS di tanahnya di Mandalika Resort Area terhadap PT. Pengembangan Pariwisata Lombok (PT. LTDC). Namun tetap, sampai sekarang, status tanah belum jelas atau memiliki kepastian hukum tertentu. Lebih lanjut, Badan Pertanahan Nasional di Lombok Center tidak ingin memproses penerbitan yang diajukan oleh ahli waris Haji Lalu Sapri CS. Badan Pertanahan Nasional di Lombok Tengah masih berpendapat bahwa tanah yang dimenangkan oleh ahli waris Haji Kemudian Sapri CS masih merupakan tanah negara. Keputusan Mahkamah Agung tidak mencabut status tanah negara ini, dan keputusan Mahkamah Agung hanya mencabut pemberian Hak Bangunan.

\section{Kata kunci : Kepastian Hukum tentang Hak Kepemilikan Tanah}

\section{PENDAHULUAN}

Permasalahan pertanahan di Nusa Tenggara Barat khususnya di Pulau Lombok mulai muncul sejak pemerintah Daerah Provinsi Nusa Tenggara Barat, merencanakan pembangunan bisnis pariwisata yaitu dari tahun 1980-an. Mulai dari sejak saat itu pihak pemerintah membuka diri dan mulai mempromosikan obyek-obyek pariwisata dan lokasi-lokasi pembangunan dan pengembangan pariwisata yang strategis. ${ }^{1}$

Sejalan dengan adanya penetapan Nusa Tenggara Barat sebagai daerah tujuan wisata, maka berbagai upaya yang dilakukan oleh pemerintah daerah untuk menggali dan mengembangkan potensi-potensi wisata yang ada. Upaya ini dilakukan karena pemerintah daerah menyadari bahwa sektor pariwisata merupakan salah satu sektor andalan yang dapat menghasilkan devisa negara pada umumnya dan dapat meningkatkan pendapatan asli daerah (PAD) khususnya, dan pada akhirnya akan dapat meningkatkan kesempatan kerja dan meningkatkan kesejahteraan masyarakat.

Sejak adanya rencana dari pemerintah provinsi Nusa Tengara Barat untuk mengembangkan bisnis pariwisata. Pemerintah Kabupaten Lombok Barat dan Kabupaten Lombok Tengah mulai membenah diri dengan melakukan penataan struktur penguasaan/pemanfaatan tanah/lahan (Land Use) di kawasan pantai. Semua kawasan tepi pantai (beach area) dijadikan sebagai kawasan pengembangan kepariwisataan. Berbagai hak atas tanah yang pernah dikeluarkan dinyatakan tidak berlaku sepanjang hak itu mengganggu pelaksanaan program kepariwisataan. Demikian juga, berbagai pejabat yang berhubungan dengan pemberian hak atau peralihan hak atas tanah (seperti notaris dihimbau untuk tidak membantu pihak pribadi yang ingin membeli atau mengusai tanah tanpa ijin pemerintah daerah.

Dengan adanya kebijakan pemerintah daerah di bidang pertanahan di kawasan pariwisata tersebut, terlihat bahwa kebijakan pemerintah daerah tersebut telah memberikan porsi yang lebih besar kepada pemilik modal untuk menguasai hak-hak atas tanah. Hal ini dimaksudkan dalam rangka mengejar pertumbuhan ekonomi, tanpa harus memperhatikan dampak dari suatu kebijakan. Kebijakan pertanahan lebih diarahkan untuk mendukung kebijakan ekonomi makro. Kebijakan pertanahan lebih merupakan bagian dari pembangunan, tidak sebagai dasar pembangunan. Kebijakan pertanahan lebih ditujukan untuk memfasilitasi kebutuhan pemilik modal. Hal ini, tentu telah mengabaikan aspek struktur penguasaan tanah, sehingga menimbulkan berbagai macam sengketa atau konflik pertanahan. ${ }^{2}$

\footnotetext{
${ }^{1}$ Arba \& Sahnan, 2007, Kajian Yuridis - Sosio-legal Pelaksanaan Kontrak Bisnis Property Dalam Rangka Pengelolaan Kawasan Pariwisata di Nusa Tenggara Barat, Laporan SPMU-TPSDP, Universitas Mataram. hlm: 2-3.

2 Sahnan, 2010, Pilihan Hukum Penyelesaian Sengketa Di Luar Pengadilan, (Studi Kasus Sengketa Tanah Hak Guna Bangunan (HGB) PT. Sinar Rowok Indah Di Kawasan Pariwisata Selong Belanak, Kabupaten Lombok Tengah, Provinsi Nusa Tenggara Barat)", Disertasi Program studi Doktor Ilmu Hukum, Malang, hlm. 7-9.
} 
Munculnya sengketa atau konflik tanah di kawasan pariwisata paling tidak disebabkan oleh 4 hal yaitu: ${ }^{3}$

1. Terjadinya ketimpangan pemilikan dan penguasaan tanah.

2. Kurangnya kemampuan dan perlindungan terhadap hak-hak rakyat.

3. Lemahnya posisi tawar rakyat dalam masalah tanah.

4. Perbedaan persepsi masyarakat pemilik tanah dengan pemerintah mengenai status hak atas tanah.

Dari penyebab muncul sengketa di atas, karena pemerintah khususnya pemerintah daerah tidak melakukan penataan struktur penguasaan tanah terlebih dahulu. Tanah warga masyarakat diambil begitu saja tanpa melalui meaknisme pembebasan yang benar. Penunjukan secara sepihak dan tidak menunjukkan batas-batas yang jelas mengenai tanah yang dibebaskan. Pada hal warga masyarakat sudah menguasai dan memiliki tanah tersebut secara turun temurun. Dari tindakan tersebut, maka tidak herang warga masyarakat melakukan perlawanan ataupun gugatan ke pengadilan. Seperti gugatan yang dilakukan oleh ahli waris dari almarhun Bapak Kemi alias Haji Lalu Sapri yaitu: Hajjah Demi Fatmah CS (Penggugat) terhadap Kepala Kantor Pertanahan Lombok Tengah (Tergugat) dan PT. Pengembangan Pariwisata Lombok (PT. LTDC. Sekarang menjadi PT. ITDC). (sebagai terggugat Intervensi) Tanah sengketa tersebut seluas 22.140 $\mathrm{M}^{2}$ terletak di Dusun Gerupuk, Desa Sengkol, Kecamatan Pujut, Kabupaten Lombok Tengah. Tanah tersebut terbagi dalam dua nama yakni: tanah seluas 15.000 . $\mathrm{M}^{2}$ atas nama Bapak Kemi alias Haji Lalu Sapri dan tanah yang seluas $7.140 \mathrm{M}^{2}$ atas nama Hajjah Demi Fatmah. ${ }^{4}$

Dalam gugatan tersebut di latarbelakangi dari adanya penolakan permohonan hak milik Hajjah Demi Fatmah oleh Kepala Kantor Pertanahan Lombok Tengah dalam kawasan tanah hak pengelolaan, tertanggal 28 Agustus 2008, Nomor 600/741/2007. Dimana dalam surat Kepala Kantor Pertanahan tersebut dikemukakan bahwa tanah yang di mohonkan oleh Hajjah Demi Fatmah tidak dapat dipertimbangkan untuk di proses dengan alasan sebagai berikut: ${ }^{5}$

1. Bahwa tanah yang dimohon tersebuttermasuk dalam sertifikat Hak Guna Bangunan (HGB) Nomor 4 Desa Sengkol tercatat atas nama PT. Pengembangan Pariwisata Lombok (PT. LTDC).

2. Berdasarkan poin angka 1 tersebut pihak Kantor Pertanahan Kabupaten Lombok Tengah tidak mempertimbangkan permohonan dan mengembalikan berkas permohonanyangdiajukantersebutsertadilakukanpencoretandaridaftar registerasi permohonan hak yang ada.

Dari gugatan Hajjah Demi Fatmah CS. Tersebut dalam Putusan Mahkamah Agung Nomor 293 K/TUN/2009 telah menguatkan Putusan Pengadilan Tinggi Tata Usaha Surabaya. Begitu juga Putusan Tinggi Tata Usaha Surabaya telah menguatkan Putusan Tata Usaha Mataram yang telah mengabulkan sebagian dari permohonan penggugat. Pengabulan gugatan penggugat sebagian yakni membatalkan Surat Keputusan Objek sengketa dan memerintahkan untuk memproses hak milik penguggat seluas $15.000 \mathrm{M}^{2}$. Karena Surat keputusan objek sengketa mencakup milik penggugat yang seluas 15.000 $\mathrm{M}^{2}$ dan telah melanggar Asas-asas Umum Pemerintahan yang Baik (asas kecermatan). ${ }^{6}$

\footnotetext{
${ }^{3}$ Ibid. hlm. 97-100.

${ }^{4}$ Putusan Mahkamah Agung Nomor 293 K/TUN/2009. hlm. 2.

${ }^{5}$ Ibid. hlm. 3

${ }^{6}$ Ibid.
} 
Kalaupun objek sengketa tersebut telah mendapat kekuatan hukum tetap namun sampai sekarang pihak Kantor Pertanahan belum memproses permohonan yang diajukan oleh Hajjah Demi Fatmah Cs. Tersebut. Maka dari apa yang dikemukakan di atas, maka permasalahannya adalah: 1. Bagaimana pengaturan Hak Pengelolaan? 2. Mengapa kepemilikan hak atas tanah di kawasan tanah hak pengelolaan Mandalika Resort tidak mendapatkan kepastian hukum?

Tulisan ini termasuk dalam jenis tulisan hukum normatif. Metode pendekatan yang digunakan adalah: pendekatan Perundang-undangan dan pendekatan kasus. Jenis bahan hukum yang diperlukan adalah: bahan hukum primer, skunder, dan tersier, yang sumber dari bahan hukum kepustakaan. Pengumpulan bahan hukum ini dengan cara studi dokumentasi. Analisis bahan hukum dilakukan secara sistematis dengan menggunakan penafsiran hukum seperti penafsiran ekstensif, penafsiran sistematis, dan penafsiran otentik

\section{PEMBAHASAN}

\section{Pengaturan Hak Pengelolaan}

Pengaturan hak pengelolaan di dalam Undang-undang Nomor 5 Tahun 1960 Tentang Peraturan Dasar Pokok-Pokok Agraria secara eksplisit tidak ditemukan. Namun hanya ditemukan secara implisit didalam penjelasan umum angka II Nomor 2 dengan menyebut "pegelolalaan".

Cikal bakal lahirnya hak pengelolaan yaitu: dari Peraturan Pemerintah Nomor 8 Tahun 1953. Dari ketentuan tersebut memang belum dikemukan apa defenisi dari hak pengelolaan, akan tetapi hanya menggunakan dengan sebutan hak Penguasaan.

A.P. Parlindungan mengemukan bahwa Istilah Hak Pengelolaan di tarik dari bahasa Belanda, yaitu Beheerscrecht yang kemudian kemudian mengartikannya dengan hak penguasaan. ${ }^{7}$ Hak Penguasaan yang dimaksud di sini adalah hak penguasaan atas tanah negara yang dikuasai oleh jawatan atau daerah swatantra.

Terminologi hak pengelolaan ditemukan pada awalnya di Peraturan Menteri Agraria Nomor 9 Tahun 1965, dan telah menunjuk bahwa hak pengelolan tidak dilahirkan dari undang-undang, melainkan melalui Peraturan Menteri Agraria. Kalaupun hak pengelolaan diatur dalam bentuk Peraturan Menteri Agraria. Namun hak pengelolaan mempunyai sifat mengikat, baik bagi pemegang Hak pengelolaan, yaitu kementeriankementerian, direktorat wilayah swatantra, maupun hak lain yang memanfaatkan tanah Hak Pengelolaan. ${ }^{8}$

Eksistensi dari hak pengelolaan menurut Boedi Harsono baru mendapatkan pengukuhannya yakni melalui Undang-Undang Nomor 16 Tahun $1985 .^{9}$ Dimana di Dalam Pasal 7 ayat (1) menyebutkan bahwa rumah susun hanya dapat dibangun di atas tanah Hak Milik, Hak Guna Bangunan, Hak Pakai atas Tanah Negara, atau Hak Pengelolaan sesuai dengan peraturan perundang-undangan yang berlaku.

Pengertian hak pengelolaan juga dapat ditemukan dalam Undang undang Nomor 21 Tahun 1997, Peraturan Pemerintah Nomor 40 Tahun 1996, Peraturan Pemerintah 24 Tahun 1997, Peraturan Menteri Agraria Negara Agraria/Kepala BPN Nomor 3 Tahun

\footnotetext{
${ }^{7}$ A.P. Parlindungan dalam Urip Santoso, 2012, Hukum Agraria Kajian Komprehensip, Cetakan ke1, Prenadamedia Group, Jakarta, hlm 158.

${ }^{8}$ Boedi Harsono dalam Urip santosa, 2013, Pedaftaran dan Peralihan Hak Atas Tanah, cet. ke 3, Prenadamedia Group, Jakarta, hlm.114.

${ }^{9}$ Ibid. hlm. 115.
} 
1997, Peraturan Menteri Negara Agraria/Kepala BPN Nomor 3 Tahun 1999, Peraturan Menteri Negara Agraria/Kepala BPN Nomor 9 Tahun 1999.

Kemudian pengaturan mengenai wewenang hak pengelolaan telah diatur di dalam Pasal 6 Peraturan Menteri Agraria Nomor 9 Tahun 1965 yakni:

1) Melakukan perencanaan peruntukan dan pemanfaatan tanah;

2) Penggunaan tanah tersebut untuk kepentingan pelaksanaan tugasnya;

3) Penyerahan bagian-bagian atas tanah tersebut kepada pihak ketiga dengan status hak pakai yang jangka waktunya 6 tahun.

4) Memberikan uang pemasukan/ganti rugi/uang wajib tahunan kepada negara.

Dari berbagai uraian yang telah dinyatakan maka dapat dikemukakan yakni Hak Pengelolaan merupakan hak yang berasal dari hak menguasai negara yang pelimpahan kewenangannya sebagian telah diserahkan kepada pemegang haknya.

Kemudian jika dilihat dari kraktristik yang dimiliki oleh Hak Pengelolaan, maka dapat dikemukan sebagai berikut $:^{10}$

a. Hak Pengelolaan adalah merupakan hak penguasaan atas tanah yang bersumber dari Hak Mengusai Negara yang kewenangannya sebagian telah diberikan kepada pihak ketiga;

b. Di samping mempunyai kewenangan, terdapat suatu kewajiban bagi pemegang haknya untuk mempergunakan tanah tersebut untuk kesejahteraan rakyat.

c. Hubungan hukum pemegang subyek dan obyek dalam Hak Pengelolaan beraspek publik, menguasai bukan dalam arti memiliki secara keperdataan, tetapi penguasaan oleh negara tersebut dilaksanakan dalam rangka: merumuskan kebijakan (beleid), melakukan pengurusan (bestuurdaad), melakukan pengaturan (regelendaad), melakukan pengelolaan (beheersdaad), melakukan pengawasan (touzichthoudendaad).

d. Hak Pengelolaan tidak mempunyai jangka waktu, karena hubungan penguasaan tersebut bersifat abadi dan tidak bisa hapus sepanjang negara kesatuan Republik Indonesia masih tetap kokoh berdiri.

e. Hak Pengelolaan tidak bisa dijadikan agunan atau menjadi obyek hak tanggungan karena mengandung aspek publik semata yang merupakan hak dari penguasaan negara yang tidak dapat dipindah tangankan.

Implikasi yuridis dari kraktristik dari Hak Pengelolan tersebut dapat dikemukakan bahwa dengan adanya pemberian hak pengelolaan kepada pemegang hak pengelolan bukan berarti putusnya hubungan hukum negara dengan tanah hak pengelolaan yang diberikan kepada pihak ketiga, melainkan pemberian hak pengelolaan kepada pemegangnya haknya sebatas pada pendelegasian wewenang kepada pemegang hak pengelolaan. Pendelegasian wewenang tersebut mencakup salah satu atau beberapa dari wewenang seperti kewenangan untuk mengatur, merencanakan dan menggunakan tanah tersebut. Kewenangan yang lain seperti kewenangan kebijakan dan pengawasan masih tetap menjadi kewenangan dari pada negara. ${ }^{11}$

Kaidah dan norma hukum tentang Pengaturan Hak Pengelolaan sesuai hakikat dan makna Hak Pengelolaan bersumber dari Pasal 33 ayat 3 UUDRI 1945. Selama ini

\footnotetext{
${ }^{10}$ Putu Juni Swasta, 2015, Pelepasan Hak Pengelolaan Dalam Peraturan Menteri Negara Agraria/Kepala Badan Pertanahan Nasional Nomor 9 Tahun 1999, Analisis Normatif Pelepasan Hak Pengelolaan Pemerintah Daerah Provinsi NTB, Dalam Rangka Pembangunan Kawasan Mandalika Resort, Tesis, Program Magister Ilmu hukum, Universitas Mataram, hlm .71-72.

${ }^{11}$ Ibid.
} 
regulasi berkaitan dengan Hak Pengelolan diatur dalam bentuk Peraturan pemerintah (PP) dan Peraturan setingkat menteri/Kepala Badan Pertanahan Nasional. Belum adanya Undang-Undang yang mengatur Hak Pengelolaan ini menimbulkan kekaburan hukum pada tataran kaidah dan norma hukum tentang Hak Pengelolaan yang mejadi pedoman dan penilaian dalam praktek menyangkut prilaku dan intraksi hukum mengenai Hak Pengelolaan. Bahkan dalam realitasnya selama ini terdapat konflik norma tentang pengaturan Hak Pengelolaan dengan hak-hak atas tanah seperti kebaradaan Hak Milik, Hak Guna Bangunan dan Hak Pakai di atas Hak Pengelolaan. Sedangkan Hak Pengelolaan regulasi pengaturannya hanya setingkat peraturan Menteri Negara Agraria/Kepala BPN Nomor 9 Tahun 1999. ${ }^{12}$

Oleh karena dewasa ini, keberadaan dari Hak Pengelolaan yang semakin mendapat tempat di dalam dinamika pembangunan, hal ini disebabkan karena di dalam bagian tanah Hak Pengelolaan masih dapat digunakan oleh pihak lain yang membutuhkannya. Maka perlu dilakukan pegaturan yang jelas terhadap Hak Pengelolaan dalam peraturan perundang-undangan. Tidak hanya diatur setingkat Peraturan Menteri, tetapi perlu di tingkatkan dalam bentuk Undang-undang. Hal ini dimaksudkan agar pihak lain yang memanfaatkan tanah Hak Pengelolaan mendapatkan suatu kepastian hukum. ${ }^{13}$

\section{Kepastian Hukum Pemilikan Hak Atas Tanah di Kawasan Tanah Hak Pengelo- laan Mandalika Resort}

Salah satu tujuan dari lahirnya UUPA adalah untuk memberikan jaminan kepastian hukum bagi seluruh rakyat Indonesia mengenai hak atas tanah. Kepastian hukum ini baru bisa tercapai apabila dengan 2 (dua) cara yakni: ${ }^{14}$

1. Memiliki sumber daya manusia di bidang hukum yang handal dan memadai yang dapat melaksanakan tugas dengan baik dan selalu berlandaskan pada semangat dan ketentuan yang berlaku.

2. Pelaksanaanpendaftarantanahyangdilakukanolehparapemeganghakdimaksudkan agar dapat melakukan pembuktian terhadap tanah yang dikuasainya, dan pihak ketiga yang mempunyai kepentingan dengan mudah mendapatkan informasi yang dibutuhkan atas objek tanah tersebut, dan terhadap pemerintah akan mudah mendapatkandatadalamkaitannyauntukmembuatdanmenerapkansuatukebijakan di bidang pertanahan.

Pendaftaran tanah, selain memberikan kepastian hukum, juga memberikan perlindungan hukum bagi pemilik atau pemegang hak atas tanah. Perlindungan hukum baru bisa terwujud apabila hak atas tanah diperoleh dengan itikad baik dan dalam realitanya mereka menguasai tanah tersebut. Maka pihak lain yang merasa punya hak tidak lagi mendapatkan kesempatan untuk melakukan penuntutan hak tersebut apabila dalam jangka waktu 5 (lima) tahun sejak sertifikat terbit, tidak dilakukan pengajuan keberatan secara tertullis kepada pemegang sertifikat dan kepada Kantor Pertanahan yang bersangkutan ataupun tidak mengajukan gugatan ke Pengadilan mengenai penguasaan tanah atau penerbitan sertifikat tersebut (lihat: Pasal 32 ayat 2 Peraturan Pemerintah Nomor 24 Tahun 1997).

Sementara itu kalapun sudah mendapatkan kepastian hukum pemilikan atau penguasaan tanah sebagaimana yang diatur dalam Pasal 32 ayat (1) PP No. 24 Tahun

\footnotetext{
${ }^{12}$ Ibid.

${ }^{13}$ Urip Santoso, Op. Cit. hlm.113.

${ }^{14}$ Ibid.
} 
1997. Akan tetapi jika cara perolehannya tidak melalui itikad baik, maka hukum tidak akan melindungi pemegang hak tersebut. Yang menjadi pertanyaannya apa yang dimaksud dengan itikad baik? Menurut P. L. Wery, yang dimaksud dengan itikad baik adalah apabila kedua pihak yakni pihak pertama dan kedua tidak saling memperdaya satu sama lain sehingga tidak menyebabkan terjadinya kerugian, tidak hanya mencari keuntungan yang bersifat pribadi, tetapi juga harus memperhatikan kepentingan pihak lain. ${ }^{15}$ Sedangkan menurut Muhammad Faisal bahwa seseorang dikatakan mempunyai itikad baik, ketika mendapatkan hak milik tersebut, jika keberadaannya pada waktu itu telah sesuai dengan ketentuan yang ada dan dia tidak mengetahui adanya cacat hukum dalam memperoleh hak milik tersebut. Permasalahan dalam pembeli beritikad baik ini terjadi karena kelemahan pengetahuan dari pembeli terhadap status obyek yang di belinya atau terdapat penipuan atau ketidakjujuran dari penjual kepada pembeli. ${ }^{16}$ Lebih lanjut Muhammad Faisal menjelaskan bahwa untuk mengetahui definisi itikad baik dalam impelementasinya, maka para pihak harus melakukan tiga hal yaitu: ${ }^{17}$

1. Masing-masing pihak harus melakukan sesuatu sesuai dengan apa yang telah diperjanjikan;

2. Masing-masing pihak tidak diperkenankan mengambil keuntungan dengan cara tipu daya;

3. Masing-masing pihak harus melaksanakan kewajibannya seperti penghormatan dan kejujuran miskipun tidak disebutkan secara jelas dalam perjanjian.

Dari pandangan di atas sudah cukup jelas mengenai apa yang dimaksud dengan itikad baik dimana orang/badan hukum dalam memperoleh barang/benda/tanah diperolehnya tidak melakukan perbuatan yang tercela dengan memperdaya atau mengganggu hak orang lain, dan tidak lebih hanya untuk mementingkan pribadi saja, melainkan juga harus memperhatikan kepentingan pihak lain juga.

Perolehan Tanah kalaupun sudah mendapat kepastian hukum, akan tetapi jika perolehannya tidak diperoleh dengan itikad baik, maka tidak akan merasa aman karena sewaktu-waktu bisa saja digugat oleh pihak yang berkentingan yang merasa di rugikan dan lebih berhak atas diterbitkannya sertifikat tersebut. Jadi Pemilik atau pemegang hak atas tanah belum merasa aman miskipun telah mempunyai sertifikat hak atas tanah. Karena sistem pendaftaran tanah yang dianut dalam Peraturan Pemerintah Nomor 24 tahun 1997 adalah sistem publisitas negatif yang bertendensi positif.

Menurut Arie Hutagalung bahwa sistem publisitas negatif yang dianut Indonesia, negara hanya bersifat pasif, artinya bahwa negara hanya menerima apa yang dikemukan oleh pihak pemohon yang meminta pendaftaran. Terhadap sertifikat yang dimiliki bisa saja dipersoalkan oleh pihak yang merasa lebih berhak atas tanah tersebut. Kalaupun perolehan tanah tersebut di peroleh dari pihak yang telah mendaftarkannya, tidak bisa menjadi jaminan, kalaupun dia peroleh dengan cara itikad baik. ${ }^{18}$

Dalam sistem publisitas negatif begitu tanah tersebut tercatat dalam buku tanah dan telah terbit sertifikat maka jaminan kepastian hukumnya sudah terwujud. Namun 131.

${ }^{15}$ Ridwan Khariady, 2013, Hukum Kontrak Indonesia Dalam Perspektif Perbandingan, UII Press, Yogyakarta, hlm.

${ }^{16}$ Widodo Dwi Putra dkk, 2016, Penjelasan Hukum Pembeli Beritikad Baik, Perlidungan Hukum Bagi Pembeli yang beritikad Baik Dalam Sengketa Perdata Berobyek Tanah, Laporan Penelitian Kerjasama Center International Legal Coorperation (CILC) Van Vollenhoven Institut (VVI), LeIP, dan Puslitbang MA, Jakarta, hlm. 31.

${ }^{17}$ Ibid.

${ }^{18}$ Arie S. Hutagalung, 2005, Tebaran Pemikiran Seputar Masalah Hukum tanah, Lembaga Pemberdayaan Hukum Indonesia, Jakarta, hlm. 86-87.

342 Jurnal IUS Kajian Hukum dan Keadilan 
perlindungan hukum belum terwujud sepenuhnya kepada pemilik sertifikat, apabila data fisik dan data yuridis yang tertulis dalam sertifikat dinyatakan benar sepanjang tidak ada pembuktian sebaliknya oleh tanda bukti yang lain, negara tidak memberi jaminan data fisik dan data yuridis dalam pendaftaran tanah adalah benar, dan pihak yang dirugikan dengan terbitnya sertifikat tersebut bisa melakukan keberatan kepada penyelenggara pendaftaran tanah untuk pembatalan sertifikat ataupun mengajukan gugatan ke pengadilan untuk meminta agar sertifikat tersebut dinyatakan tidak sah. ${ }^{19}$

Dari pandagan di atas apabila di pertalikan dengan kasus sengketa tanah di atas kawasan tanah hak pengelolaan Mandalika Resort dalam Putusan MA Nomor 293 K/ TUN/2009 terlihat bahwa:

Mahkamah Agung dalam Putusannya telah menolak permohonan kasasi dari Pemohon Kasasi I : PENGEMBANGAN PARIWISATA LOMBOK (PT. LTDC) dan Pemohon Kasasi II: KEPALA KANTOR PERTANAHAN KABUPATEN LOMBOK TENGAH tersebut; dan menghukum Pemohon Kasasi I/Tergugat II Intervensi dan Pemohon Kasasi Il /Tergugat I untuk membayar biaya perkara sebesar Rp.500.000, (lima ratus ribu rupiah).

Adapun dasar pertimbangan hakim menolak kasasi yang diajukan oleh Pemohon Kasasi I/Tergugat II Intervensi dalam memori kasasinya tersebut pada pokoknya didasarkan pada suatu alasan dari Pemohon Kasasi I/Tergugat II intervensi yang telah dikemukan mulai dari alasan Nomor 1 (satu) sampai dengan 6 (enam) tidak dapat dibenarkan. Adapun alasan-alasan kasasi dari permohon Kasasi I/ Tergugat II Intervensi tersebut dapat dikemukan sebagai berikut: ${ }^{20}$

1. Di dalam putusan Pengadilan Tinggi Tata Usaha Negara Surabaya sudah tidak benar di dalam menerapkan hukum dan sudah keliru di dalam memberikan pertimbangan hukumnya, hal ini terlihat dari pertimbangan yang diberikan oleh Majelis Hakim PengadilanTinggiTataUsahaNegaraSurabayaNO.28/B/2009/PT.TUN.SBY.tanggal 8 april 2009 jo. Putusan Pengadilan Tata Usaha Negara Mataram No.17/G/2008/ PTUN.MTR. tanggal 16 Desember 2008 dengan tidak memberikan pertimbangan kepada seluruh bukti-bukti yang sudah diajukan oleh Pemohon Kasasi/Tergugat II Intervensi;

2. Pemohon Tergugat II Intervensi memperoleh Hak Guna Bangunan Nomor 4 Desa Sengkol atas nama PT. Pengembangan Pariwisata Lombok (PT.LTDC) yang diterbitkan oleh Kepala Kantor Pertanahan Kabupaten Lombok Tengah telah sesuai denganproseduryangsahdansesuaidenganketentuanperundang-undangan, karena perolehannya sesuai dengan prosedur yaitu sebelum melakukan pembayaran ada pengecekan lokasi sebagaimana keadaan tanah, apakah tanah tersebut bersertifikat atau tanah Negara dikuasai atau Tanah Negara Bebas. Oleh karena tanah objek sengketa kegunaannya dan bukti penguasaan tidak ada garapan dan tidak ada penggarap, maka tanah tersebut betul-betul merupakan kategorikan sebagai Tanah Negara Bebas sehingga ganti rugi diberikan kepada Negara, sehingga sudah sesuai dengan ketentuan prosedur dan ketentuan perundang-undangan;

3. Termohon Kasasi/Penggugat sebelumya pernah mengajukan gugatan pada tanggal 5 Nopember 2007 dalam perkara No.25/G.TUN/2007/PTUN.MTR. atas objek sengketa Hak Guna Bangunan No.4/Desa Sengkol tanggal 20 Januari 1994 atas

\footnotetext{
${ }^{19}$ Urip Santoso, 2015, Perolehan Hak Atas Tanah, Cet. I, Prenadamedia Group, Jakarta, hlm.171.

${ }^{20}$ Putusan Mahkamah Agung Nomor 293 K/TUN/2009. hlm. 9-11.
} 
nama PT. Pengembangan Pariwisata Lombok (PT. LTDC) dan oleh Pengadilan Tata Usaha Negara Mataram dalam putusannya tanggal 12 Juni 2008 telah memutus : gugatan Penggugat tidak dapat diterima (Niet Onvantkelijke Verklaard) kemudian Penggugat kembali mengajukan gugatan pada tanggal 25 Juli 2008 No.17/G/2008/ PTUN.MTR, gugatan Penggugat dikabulkan untuk sebagian. Terhadap putusanputusan yang diberikan tersebut, Penggugat II Intervensi tidak sependapat dengan Majelis Hakim karena Hakim Pengadilan Tata Usaha Negara Mataram telah salah menerapkan hukum Pasal 55 Undang-Undang Nomor 5 Tahun 1985 diubah dengan Undang-Undang Nomor 9 Tahun 2004 tentang Peradilan Tata Usaha Negara karena gugatandiajukantidakdalamtenggangwaktuyangditentukanolehUndang-Undang, dan Majelis Hakim dalam hal ini tidak cermat dalam meneliti dan menilai alat bukti T-1 dan T-2 yang diajukan. Berdasarkan alasan-alasan tersebut sudah sepatutnya dan seharusnya gugatan penggugat ditolak ;

4. Putusan dari judex facti Pengadilan Tinggi Tata Usaha Negara Surabaya senantiasa mengkait-kaitkan hubungan antara Hak Pengelolaan Nomor 1/Desa Sengkol tanggal 20 Juli 1992 atas nama Pemerintah Provensi Daerah Tingkat I Nusa Tenggara Barat dengan Hak Guna Bangunan Nomor 4/Desa Sengkol tanggal 20 Januari 1994 atas nama PT. Pengembangan Pariwisata Lombok (PT.LTDC) menjadi satu kesatuan yang tidak terpisahkan antara kedua jenis hak tersebut. Jelas-jelas telah mengaburkanpermasalahandaripokokpersoalannyasehinggamenjadibiasa, karena yang sebenarnya adalah :

a. Sertifikat hak pengelolaan Nomor 1/Desa Sengkol tanggal 20 Juli 1992 luas 949.117 $\mathrm{M}^{2}$ atas nama Pemerintah Propinsi Daerah Tingkat I Nusa Tenggara Barat diterbitkan berdasar pada ketentuan peraturan sebagaimana pertimbangan hukum Majelis Hakim a quo, maka penerbitan sertifikat hak pengelolaan No.1/Desa Sengkol, telah sah secara hukum. Dalil-dalil gugatan Penggugat sepanjang mengenai pembebasan tanah. Pembayaran ganti rugi tanah akan terbantahkan apabila hak pengelolaan Nomor 1/Desa Sengkol tanggal 20 Juli 1992 luas 949.117 M² atas nama Pemerintah Propinsi Daerah Tingkat I Nusa Tenggara Barat dijadikan sebagai objek gugatan ;

b. Sertifikat Hak Guna Bangunan Nomor 4/Desa Sengkol tanggal 20 Januari 1994 luas $949.117 \mathrm{M}^{2}$ atas nama PT. Pengembangan Pariwisata Lombok (PT. LTDC) diterbitkan atas hak pengelolaan Nomor 1/Desa Sengkol tanggal 20 Juli 1992 berdasar pada ketentuan Peraturan Menteri Dalam Negeri Nomor 1 Tahun 1997;

c. Dari uraian angka 4a dan b di atas jelas bahwa permasalah-masalahan hukum yang timbul akibat dari gugatan ini, karena hukum hanya tertuju pada diterbitkannya hak Pengelolaan Nomor 1/Desa Sengkol tanggal 20 Juli 1992 luas 949.117 M2 atas nama Pemerintah Daerah Tingkat I Nusa Tenggara Barat bukan pada diterbitkannya Hak Guna Bangunan Nomor 4/Desa Sengkol Tangga! 20 Januari 1994 atas nama PT. Pengembangan Pariwisata Lombok (PT. LTDC) ;

5. Dari putusan judex facti Pengadilan Tata Usaha Negara Mataram pada halaman 47-48 jo. Putusan judex facti Pengadilan Tinggi Tata Usaha Negara Surabaya pada halaman 29-30 telah keliru/tidak cermat dalam menerapkan hukum Tata Usaha Negara telah memisahkan keputusan pejabat negara yang merupakan satu kesatuan 
yaitu keputusan pejabat negara terhadap Hak Pengelolaan dan Hak Guna Bangunan, sehingga tidak mempunyai kepastian hukum terhadap pembatalan Hak Guna Bangunan apabila Hak Pengelolaan tidak dibatalkan.

6. Dari apa yang telah di kemukakan dalam putusan judex facti Pengadilan Tinggi Tata Usaha Negara Surabaya pada halaman 31 adalah sangat keliru dan tidak cermat karena disatu sisi menyatakan bahwa sertifikat Hak Pengelolaan No.1/Desa Sengkol atas nama Pemerintah Nusa Tenggara Barat tidak dibatalkan, tetapi bertentangan dengan PP No.1 Tahun 1961 dan PMDN Nomor 15 Tahun 1975 dan asas-asas pemerintahyangbaikyaituasaskecermatandanasaskehati-hatian,karenaditerbitkan sertifikat atas tanah yang sedang digarap/dikuasai oleh Bapak Kemi alias H. Lalu Sapri beserta ahli warisnya, disisi lain Sertifikat Hak Guna Bangunan dibatalkan, sedangkan yang dianggap dan bertentangan adalah kedua sertifikat hak tersebut sehingga dapat dikatakan bahwa putusan judex facti Pengadilan Tinggi Tata Usaha Negara Surabaya dan Pengadilan Tata Usaha Negara Mataram mengakui bahwa kedua hak tersebut tidak dapat dipisahkan;

Sedangkan dasar penolakan Mahkamah Agung terhadap Pemohon Kasasi II/Tergugat adalah karena alasan dari pemohon kasasi dari Nomor 1 dan 2 tidak dapat dibenarkan. Adapun alasan-alasan menimbangnya pada pokoknya adalah sebagai berikut: ${ }^{21}$

1. Putusan judex facti Pengadilan Tinggi Tata Usaha Negara Surabaya No.28/B/2009/ PT.TUN.SBY. pada tanggal 8 April 2009 sudah salah di dalam menerapkan hukum, dalam menilai dan memutus perkara sehubungan dengan diterbitkannya sertifikat Hak Guna Bangunan Nomor 4/Desa Sengkol tanggal 20 Januari 1994 luas 949,117 M² atas nama PT. Pengembangan Pariwisata Lombok (LTDC) vide bukti T-II Int. 1 sebagaimana dalam pertimbangan hukumnya yang didasarkan pada ketentuan peraturan sebagai berikut :

- Pasal 3 ayat (2) PP Nomor 10 Tahun 1961;

- Pasal 3 ayat (4) PP Nomor 10 Tahun 1961;

- Pasal 4 PMDN ayat (1), ayat (2), ayat (3) Nomor 15 Tahun 1975;

- Pasal 6 PMDN Nomor 15 Tahun 1975 ;

Menurut TergugatI/pembanding II Adalah tidak tepatkarena ketentuan-ketentuan peraturan tersebut di atas hanya diterapkan pada saat penerbitan sertifikat untuk pertamakalinya (original) sepertiHak Pengelolaan Nomor 1/Desa Sengkolluas949.117 $\mathrm{M}^{2}$ atas nama Pemerintah Propinsi Daerah Tingkat I Nusa Tenggara Barat (vide bukti T.6 dan T.II Int.2) dan pada saat diterbitkan sertifikat Hak Pengelolaan Nomor 1 Desa Sengkol tidak ada pihak lain yang merasa dan mengajukan keberatan kecuali gugatan ini. Tidak adanya yang mengajukan keberatan yang diajukan oleh pihak lain maka penerbitan Hak Pengelolaan Nomor 1 Desa Sengkol sudah tidak ada masalah baik dari segi penguasaan secara fisik maupun yuridis sehingga penerbitan sertifikat Hak Pengelolaan Nomor 1 Desa Sengkol atas nama Pemerintah Propinsi Daerah Tingkat I Nusa Tenggara Barat, adalah sah dan telah sesuai dengan prosedur hukum;

Sedangkan dalam sertifikat Hak Guna Gangunan Nomor 4/Desa Sengkol tanggal 20Januari 1994 atas nama PT. Pengembangan Pariwisata Lombok (LTOC) luas 949.117 $\mathrm{M}^{2}$ (objek sengketa) diterbitkan di atas Hak Pengelolaan Nomor 1/Desa Sengkol, luas 949.117 $\mathrm{M}^{2}$ atas nama Pemerintah Propinsi Daerah Tingkat I Nusa Tenggara

\footnotetext{
${ }^{21}$ Ibid. hlm. 12-17.
} 
Barat. Penerbitan sertifikat Hak Guna Bangunan No.4/Desa Sengkol tidak tergolong penerbitan sertifikat untuk pertama (original) karena diterbitkan dinas HPL No.1/ Desa Sengkol maka ketentuan peraturan yang mendasarinya adalah PMDN No.1 Tahun 1977. dst.......

2. Judex facti Pengadilan Tinggi Tata usaha Negara Surabaya telah keliru dan salah di dalam memberikan penilaian terhadap memori banding Tergugat/Pembanding sebagai pertimbangan hukum di halaman 32 alinea 32 kedua kalinya: dalam memori banding yang diajukan Tergugat/Pembanding dan Tergugat II Intervensi/Pembanding sama sekali tidak melemahkan pertimbangan hukum dalam memori banding Hakim Pengadilan Tata Usaha Negara Mataram, pada hal didalam memori banding Tergugat/ Pembanding telah melakukan bantahan terhadap pertimbangan hukum yang diberikan oleh judex facti Pengadilan Tata Usaha Negara Mataram karena menilai Hak Guna Bangunan Nomor 4/Desa Sengkol yang mendasarkan pada ketentuan peraturan yang tidak tepat (memori banding Tergugat/pembanding angka 4).

Dari alasan tersebut di atas, Mahkamah Agung telah menolak Permohonan Kasasi I/ Tergugat II Intervesi dan Pemohon Kasasi II/Tergugat dengan dasar pertimbangan bahwa alasan-alasan penolakan tersebut adalah sebagai berikut: ${ }^{22}$

1. Putusan Judex facti Pengadilan Tinggi Tata Usaha Negara Surabaya sudah benar di dalam menerapkan hukum, di samping itu juga pada hakekatnya, dimana di dalam menilai suatu bukti yang bersifat penghargaan terhadap suatu realita, tidak bisa di jadikan bahan pertimbangan dalam pemeriksaan di tingkat kasasi, karena tingkatkasasi hanya berkaitan dengan adanya suatu kekeliruan yang dijadikan dasar di dalam memutus suatu perkara, terjadinya pelanggaran hukum yang berlaku, adanya suatu kelalaian dengan tidak terpenuhi persyaratan-persyaratan yang telah di haruskan menurut ketentuan yang berlaku yang telah memberikan sanksi atas kelalaian tersebut dengan melakukan pembatalan terhadap putusan yang ada atau jika Pengadilan tidak mempunyai wewenangan atau telah melampaui batas wewenang sebagaimana yang di maksud dalam Pasal 30 Undang-Undang No.14 Tahun 1985 sebagaimana telah diubah dengan Undang-Undang No.5 Tahun 2004 dan perubahan kedua dengan Undang-Undang No.3 Tahun 2009.

2. JudexfactiPengadilanTinggiTataUsahaNegaraSurabayatelahmengabulkangugatan Penggugat sebagian, dengan melakukan pembatalan terhadap Surat Keputusan Objek Sengketa dan memerintahkan kepada Kantor Pertanahan Kabupaten Lombok Tengah untuk memproses hak milik Penggugat 15.000 M2 adalah tepat, karena Surat Keputusan Objek Sengketa mencakup milik Penggugat seluas15.000 M2 dan melanggar asas-asas umum pemerintahan Yang baik (asas kecermatan).

Dari Putusan Mahkamah Agung tersebut di atas telah menguatkan isi putusan hakim tingkat banding, begitu juga putusan tingkatbanding telah menguatkan Putusan Pengadilan Tata Usaha Negara Mataram, karena dari penguasaan yang dilakukan Pemohon Kasasi I/Tergugat II tidak mampu membuktikan di sidang pengadilan bahwa tanah yang masuk dalam serifikat Hak Guna Bangunan (HGB) di atas tanah kawasan hak pengelolaan tersebut memang merupakan tanah negara diperoleh dengan itikad baik dengan data yuridis dan data fisik yang diajukan adalah benar sebagai bukti penguasaan untuk memperoleh sertifikat Hak Guna Bangunan (HGB) Nomor 4 Desa Sengkol atas nama PT Pengembangan Pariwisata Lombok (LTDC).

\footnotetext{
${ }^{22}$ Ibid. hlm 17-18.
} 
Begitu juga dari pihak Pemohon Kasasi II/ Tergugat tidak mampu membuktikan bahwadatayangdiajukanolehpihaktergugatIImemangdatayangbenar.Danseharusnya pihak Tergugat tidak bersifat aktif karena data yang diajukan oleh Pemohon Kasasi/ tergugat II yang harus aktif untuk membuktikan hak yang diperolehnya. Karena dari bukti tertulis yang diajukan oleh pihak termohon kasasi/penggugat tersebut adalah harus mampu dipatahkan kebenarannya. Seperti bukti-bukti yang diajukan oleh pihak penggugat/termohon kasasi itu antara lain adalah berupa: ${ }^{23}$

1. Surat Keterangan pemilikan atas tanah Nomor 75/V/1987 seluas $15.000 \mathrm{M}^{2}$ yang di tanda tangani kepala Desa Sengkol tanggal 1 Mei 1989 atas nama Bapak Kemi;

2. GambarLokasiyangdikeluarkanolehBadanpertanahannasionalkabupatenLombok Tengah atas tanah 22.140 $\mathrm{M}^{2}$ atas nama Bapak Kemi;

3. Surat Pemberitahuan Pajak Terhutang (SPPT) Pajak Bumi dan Bangunan dari tahun 1992 sampai dengan 2007 terkecuali tahun 1994 dan 1995 atas nama Bapak Kemi;

4. Pernyataan penguasaan fisik bidang tanah (sporadik) atas tanah $15.000 \mathrm{M}^{2}$ atas nama Bapak Kemi alias Haji lalu Sapri yang dikeluarkan oleh Kepala Desa Sengkol Nomor 02/03/2007.

Jadi dapat juga di kemukan bahwa Legalitas penguasaan yang di miliki oleh PT. Pengembangan Pariwisata Lombok (PT LTDC) dalam praktik hukum tidak menutup kemungkinan penguasaan tersebut akan dipersoalkan atau terjadinya sengketa, walaupun sudah memiliki sertifikat. Sengketa hak atas tanah melahirkan kedaan ketidak pastian hukum bagi mereka yang memiliki sertifikat hak atas tanah. Di satu sisi negara menjamin kepastian hukum akan hak atas tanah bentuk legalisasi sertifikat, akan tetapi dipihak lain hukum memberikan ruang hak atas tanah dapat di gugat di pegadilan pada hal sudah melekat sertifikat hak atas tanah pada objek tanah tersebut. ${ }^{24}$

\section{SIMPULAN}

Pengaturan Hak Pengelolaan pada hakikatnya bersumber dari Pasal 33 ayat 3 UUDRI 1945. Pengaturannya lebih lanjut bisa ditemukan di dalam UUPA walaupun hanya dikemukakan secara implisit di dalam penjelasan umum angka II Nomor 2. Pengaturan mengenai Hak pengelolaan lebih kongkrit seharusnya diatur dalam bentuk Undangundang, bukan dalam bentuk Peraturan Menteri. Landasan hukumnya yang hanya sebatas peraturan menteri, tentu keberadaan hak pengelolaan posisinya menjadi lemah, karena ini menyangkut kepentingan rakyat banyak. Maka sepatutnya hak pengelolaan mempunyai ligitimasi yang kuat dengan diatur dengan Undang-undang atau serendahrendah dalam bentuk Peraturan Pemerintah.

Sampai saat ini kepemilikan tanah seluas $15000 \mathrm{M}^{2}$ di kawasan tanah hak pengelolaan Mandalika Resort yang dimenangkan melalui pengadilan oleh ahli waris Haji Lalu Sapri CS belum ada kepastian hukumnya. Karena pihak Kepala kantor Pertanahan Kabupaten Lombok Tengah tidak mau memproses penerbitan sertifikat yang diajukan oleh pihak ahli waris dari Haji Lalu Sapri CS. Pihak Kantor Pertanahan Kabupaten Lombok Tengah masih bersikukuh dan berpandangan bahwa tanah yang dimenangkan oleh pihak ahli waris dari alm. Haji Lalu Sapri CS tersebut adalah statusnya masih tanah negara bebas, dan status tanah tersebut tidak dicabut dalam putusan Mahkamah Agung, hanya saja

\footnotetext{
${ }^{23}$ Putusan Pengadilan Tata Usaha Negara Mataram Nomor: 25/G.TUN/2007/PTUN-Mataram, hlm 16-18.

${ }^{24}$ Ratih Mutiara Louk Panggi, 2020, Kekuatan Pembuktian Sertifikat Hak Milik Atas Tanah Dalam Perkara Warisan (Studi Putusan Pengadilan Agama Nomor 504/Pdt.G/2002/PA.SEL), Tesis, Program Studi Magister Ilmu Hukum Fakultas Hukum, Universitas Mataram, Mataram, hlm. 4-5.
} 
yang dicabut adalah pemberian Hak Guna Bangunan terhadap tanah yang seluas 15000 $\mathrm{M}^{2}$ kepada PT. Pengembangan Pariwisata Lombok (PT. LTDC).

\section{DAFTAR PUSTAKA}

\section{Buku}

Arie S. Hutagalung, (2005), Tebaran Pemikiran Seputar Masalah Hukum tanah, Lembaga Pemberdayaan Hukum Indonesia, Jakarta

Ridwan Khariady, (2013), Hukum Kontrak Indonesia Dalam Perspektif Perbandingan, UII Press, Yogyakarta.

Urip Santoso, (2012), Hukum Agraria Kajian Komprehensip, Cetakan ke1, Prenadamedia, Jakarta.

, (2013), Pedaftaran dan Peralihan Hak Atas Tanah, cetakan 3, Prenadamedia Group, Jakarta.

, (2015) Perolehan Hak Atas Tanah, Cetakan I, Prenadamedia Group, Jakarta.

\section{Hasil Penelitian}

Arba \& Sahnan, (2007), Kajian Yuridis - Sosio-legal Pelaksanaan Kontrak Bisnis Property Dalam Rangka Pengelolaan Kawasan Pariwisata di Nusa Tenggara Barat, Laporan SPMU-TPSDP, Fakultas Hukum Universitas Mataram, Mataram

Widodo Dwi Putra dkk, (2016), Penjelasan Hukum Pembeli Beritikad Baik, Perlidungan Hukum Bagi Pembeli yang beritikad Baik Dalam Sengketa Perdata Berobyek Tanah, Laporan Penelitian Kerjasama Center International Legal Coorperation (CILC), Van Vollenhoven Institut (VVI) dari Universitas Leiden, LeIP, dan Puslitbang MA, Mahkamah Agung, Jakarta.

\section{Tesis}

Putu Juni Swasta, (2015), Pelepasan Hak Pengelolaan Dalam Peraturan Menteri Negara Agraria/Kepala Badan Pertanahan Nasional Nomor 9 Tahun 1999, Analisis Normatif Pelepasan Hak Pengelolaan Pemerintah Daerah Provinsi NTB, Dalam Rangka Pembangunan Kawasan Mandalika Resort, Tesis, Program Studi Magister Ilmu Hukum, Universitas Mataram, Mataram.

Ratih Mutiara Louk Panggi, (2020), Kekuatas Pembuktian Sertifikat hak Milik Atas Tanah Dalam Perkara Warisan (Studi Putusan Pengadilan Agama Nomor 504/Pdt.G/2002/PA.SELONG), Tesis, Program Studi Magister Ilmu Hukum Universitas Mataram, Mataram.

\section{Disertasi}

Sahnan, (2010), Pilihan Hukum Penyelesaian Sengketa Di Luar Pengadilan, (Studi Kasus Sengketa Tanah Hak Guna Bangunan (HGB) PT. Sinar Rowok Indah Di Kawasan Pariwisata Selong Belanak, Kabupaten Lombok Tengah, Provinsi Nusa Tenggara Barat), Disertasi, Program studi Doktor Ilmu Hukum, Fakultas Hukum, Universtas Brawijaya, Malang.

\section{Peraturan Perundang-undangan}

Undang-Undang Dasar Republik Indonesia 1945.

Undang-Undang Nomor 5 Tahun 1965 tentang Peraturan Dasar Pokok-Pokok Agraria 
(Lembaran Negara Tahun 1960 Nomor 104, Tambahan Lembaran Negara Nomor 2043.

Undang-Undang Nomor 16 Tahun 1985 tentang Rumah Susun.

Undang-undang Nomor 21 Tahun 1997 tentang Bea Perolehan Hak Atas Tanah dan Bangunan.

Peraturan Pemerintah Nomor 8 Tahun 1953 tentang Penguasaan Tanah-Tanah Negara.

Peraturan Pemerintah Nomor 10 Tahun 1961 tentang Pendaftaran Tanah

Peraturan Pemerintah Nomor 24 Tahun 1997 tentang Pendaftaran Tanah

Peraturan Menteri Agraria Nomor 9 Tahun 1965 tentang Pelaksanaan Konversi Hak Penguasaan atas Tanah Negara dan Kebijaksaan selanjutnya.

Peraturan Pemerintah Nomor 40 Tahun 1996 tentang Hak Guna Usaha, Hak Guna Bangunan, Hak Pakai Atas Tanah.

Peraturan Menteri Dalam Negeri Nomor 5 Tahun 1973 tentang Tata Cara Pemberian Hak Atas Tanah.

Peraturan Menteri Dalam Negeri Nomor 15 Tahun 1975 tentang Ketentuan-Ketentuan mengenai Tata Cara PembebasanTanah

Peraturan Menteri Dalam Negeri Nomor 1 Tahun 1977 tentang : Tata Cara Permohonan dan Penyelesaian Pemberian Hak Atas Bagian - bagian Tanah Hak Pengelolaan serta Pendaftarannya.

Peraturan Menteri Negara Agraria/Kepala BPN Nomor 3 Tahun 1997 tentang Ketentuan Pelaksanaan Peraturan Pemerintah Nomor 24 Tahun 1997 tentang Pendaftaran Tanah.

Peraturan Menteri Negara Agraria/Kepala BPN Nomor 9 Tahun 1999 tentang Tata Cara Pemberian Dan Pembatalan Hak Atas Tanah Negara dan Hak Pengelolaan.

Peraturan Menteri Negara Agraria/Kepala BPN Nomor 3 Tahun 1999 tentang Pelimpahan Kewenangan Pemberian Dan Pembatalan Keputusan Pemberian Hak Atas Tanah Negara.

Putusan Peradilan

Putusan Mahkamah Agung Nomor 293 K/TUN/2009.

Putusan Pengadilan Tata Usaha Negara Mataram Nomor: 25/G.TUN/2007/PTUNMataram. 